\title{
ИНФЕКЦИОННЫЕ БОЛЕЗНИ INFECTIOUS DISEASES
}

\section{ОЦЕНКА ЭФФЕКТИВНОСТИ ВАКЦИНАЦИИ НАСЕЛЕНИЯ ПРОТИВ ЧУМЫ В ТУВИНСКОМ ПРИРОДНОМ ОЧАГЕ. СООБЩЕНИЕ 2: ДИНАМИКА ПОКАЗАТЕЛЕЙ ИММУННОГО СТАТУСА ПОСЛЕ РЕВАКЦИНАЦИИ}

\section{PEЗЮME}

Корытов К.М. ${ }^{1}$, Дубровина В.И. ${ }^{1}$, Войткова В.В. ${ }^{1}$, Пятидесятникова А.Б. ${ }^{1}$, Глушков Э.А. ${ }^{2}$ Акимова И.С. ${ }^{2}$, Ондар Н.B. ${ }^{2}$, Салчак Л.К. ${ }^{3}$ Сайды А.A. ${ }^{4}$, Ортеней Ю.К. 5 , Балахонов С.В. ${ }^{1}$

\footnotetext{
1 ФКУЗ Иркутский научноисследовательский противочумный институт Сибири и Дальнего Востока Федеральной службы по надзору в сфере защиты прав потребителей и благополучия человека (664047, г. Иркутск, ул. Трилиссера, 78, Россия) 2 ФКУЗ «Тувинская противочумная станция» Федеральной службы по надзору в сфере защиты прав потребителей и благополучия человека (667010, г. Кызыл, ул. Московская, 13, Россия)

3 Управление Федеральной службы по надзору в сфере защиты прав потребителей и благополучия человека по Республике Тыва (667010, г. Кызыл, ул. Калинина, 116, Россия)

4 Территориальный отдел Управления Федеральной службы по надзору в сфере защиты прав потребителей и благополучия человека по Республике Тыва в Овюрском районе (668130, с. Хандагайты, ул. Октябрьская, 20, Россия)

5 ГБУЗ РТ «Овюрская центральная кожуунная больница» (668130, с. Хандагайты, ул. Октябрьская, 1, Россия)
}

Автор, ответственный на переписку: Дубровина Валентина Ивановна, e-mail: dubrovina-valya@mail.ru ния.

\begin{abstract}
Актуальность. Основное место в эпидемиологическом надзоре и защите от чумы на эндемичных территориях отведено специфической профилактике. В России применяют живую чумную вакцину (ЖЧВ), которая способствует развитию иммунитета до года. Ежегодная ревакцинация жителей, проживающих на территории природныхочагов чумы, обусловливает высокую антигенную нагрузку на организм. Актуальным направлением исследований является иммунологический мониторинг местного населения с целью поиска информативных маркеров, совершенствования тактики эпидемиологического надзора за чумой и внедрения персонифицированного подхода при проведении специфической профилактики. Данная работа является продолжением комплексных исследований по оценке эффективности вакцинации местного населения против чумы, проводимых в Республике Тыва. Цель работы - оценить показатели клеточного и гуморального иммунитета у ревакцинированных ЖЧВ людей, постоянно проживающих и осуществляющих свою трудовую деятельность на территории Тувинского природного очага чумы.
\end{abstract}

Материалы и методы. В исследовании приняли участие 76 добровольцев из с. Хандагайты Республики Тыва, ревакцинированных ЖЧВ. Забор крови проводили до вакцинации, а также через 1, 3 и 6 месяцев после ревакцинации в 2018-2019 г2. Исследование материала включало определение продукции биомаркерных цитокинов (IFN-y, IL-4, TNF-a) клеток крови, специфических антител, основных классов иммуноглобулинов (IgM, IgG, IgA и IgE) в сыворотке крови и субпопуляционный состав лимфоцитов крови (CD3, CD4, CD8, CD16, CD19, иммунорегуляторный индекс).

Результаты. Установлено снижение IgG и IgM и повышение IgA после вакцинации ЖЧВ и их увеличение после ревакцинации. Уровень IgЕ варьировал в пределах физиологической нормы. Выявлены коррелячионные взаимосвязи между иммуноглобулинами, B-клетками и IL-4. Ревакцинация приводит к увеличению сероконверсии в исследуемой группе. Об активации звеньев гуморального иммунитета организма людей, вакцинированных против чумы, также свидетельствует динамика изменения субпопуляционного состава - возрастание $B$-лимфоцитов и натуральных киллеров, снижение T-хелперов и иммунорегуляторного индекса, а о стимуляции клеточного иммунитета - повышение спонтанной и индуцированной продукции прои противовоспалительных цитокинов.

Заключение. Показано, что ЖЧВ способна вызвать иммунную перестройку организма и активировать клеточные и гуморальные механизмы иммунологической защиты. Показатели иммунного статуса вакцинированных/ ревакцинированных людей варьируют в пределах референсных значений. Для полного понимания развития и сохранения противочумного иммунитета необходимо продолжить ежегодный иммунологический мониторинг за населением, проживающим на территории Тувинского природного очага чумы, с привлечением дополнительных современных методик исследова-

Ключевые слова: чума, природный очаг, вакцинация, кровь, иммуноглобулин, цитокин, иммунофенотипирование 
Статья получена: 27.05.2021

Статья принята: 14.09.2021

Статья опубликована: 17.11.2021
Для цитирования: Корытов К.М., Дубровина В.И., Войткова В.В., Пятидесятникова А.Б., Глушков Э.А., Акимова И.С., Ондар Н.В., Салчак Л.К., Сайды А.А., Ортеней Ю.К., Балахонов С.В. Оценка эффективности вакцинации населения против чумы в Тувинском природном очаге. Сообщение 2: динамика показателей иммунного статуса после ревакцинации. Acta biomedica scientifica. 2021; 6(5): 44-56. doi: 10.29413/ABS.2021-6.5.5 


\section{EFFICIENCY OF HUMAN PLAGUE VACCINATION IN TUVINIAN NATURAL PLAGUE FOCUS. MESSAGE 2: DYNAMICS OF IMMUNE STATUS INDICATORS AFTER REVACCINATION}

\author{
Korytov K.M. ${ }^{1}$, \\ Dubrovina V.I. ${ }^{1}$ \\ Voytkova V.V. ${ }^{1}$, \\ Pyatidesyatnikova A.B. ${ }^{1}$, \\ Glushkov E.A. ${ }^{2}$, \\ Akimova I.S. ${ }^{2}$, \\ Ondar N.V. ${ }^{2}$ \\ Salchak L.K. ${ }^{3}$, \\ Saydy A.A. ${ }^{4}$, \\ Orteney Yu.K. ${ }^{5}$, \\ Balakhonov S.V. ${ }^{1}$ \\ 1 Irkutsk Antiplague Research \\ Institute of Siberia and Far East \\ of Rospotrebnadzor (Trilissera str. 78, \\ Irkutsk 664047, Russian Federation) \\ 2 Tuvinian Antiplague Station \\ of Rospotrebnadzor (Moskovskaya str. \\ 13, Kyzyl 667010, Russian Federation) \\ 3 Regional Office of Rospotrebnadzor \\ in Republic of Tuva (Kalinina str. 116, \\ Kyzyl 667010, Russian Federation) \\ ${ }^{4}$ Territorial Office of Rospotrebnadzor \\ in Ovyur District (Oktyabrskaya str. \\ 20, Khandagayty 668130, Russian \\ Federation) \\ ${ }^{5}$ Ovyur Central Kozhuun Hospital \\ (Oktyabrskaya str. 1, Khandagayty \\ 668130, Russian Federation)
}

Corresponding author: Valentina I. Dubrovina, e-mail dubrovina-valya@mail.ru

\section{ABSTRACT}

Relevance. In Russia, the live plague vaccine (LPV) is used for specific prophylaxis of plague. Immunological monitoring of humans vaccinated by LPV in order to search for informative diagnostic markers, as well as to improve the tactics of epidemiological surveillance of plague enzootic territories is an urgent area of research.

The aim is to assess the parameters of cellular and humoral immunity in humans revaccinated by LPV who permanently reside on territory of the Tuvinian natural plague focus.

Materials and methods. The study involved 76 volunteers from the Republic of Tuva, revaccinated by $L P V$. Blood sampling was performed before vaccination and 1, 3, and 6 months after revaccination. The study included the determination of cytokine production (IFN- $\gamma$, IL-4, TNF-a), specific antibodies, immunoglobulins (IgM, IgG, IgA and $\lg E$ ) and lymphocyte subpopulation composition (CD3, CD4, CD8, CD16, CD19, immunoregulatory index).

Results. A decrease in Ig G and IgM and an increase in IgA were found after vaccination with $L P V$ and their increase after revaccination. Correlation relationships were revealed between immunoglobulins, $B$ cells and IL-4. Revaccination leads to an increase seroconversion. The activation of humoral immunity in humans vaccinated against plague is also evidenced by dynamics of changes in the subpopulation composition: an increase in B-lymphocytes and natural killer cells, a decrease in T-helpers and immunoregulatory index, and cellular immunity stimulation is an increase in spontaneous and induced production of pro- and anti-inflammatory cytokines. Conclusion. It has been shown that LPV is capable of causing the body's immune restructuring and activating the cellular and humoral mechanisms of immunological protection. For a complete understanding of the development and preservation of antiplague immunity, it is necessary to continue the annual immunological monitoring of the population living on the territory of the Tuvinian natural plague focus, using additional modern research methods.

Key words: plague, natural focus, vaccination, blood, immunoglobulin, cytokine, immunophenotyping

For citation: Korytov K.M., Dubrovina V.I., Voytkova V.V., Pyatidesyatnikova A.B., Glushkov E.A., Akimova I.S., Ondar N.V., Salchak L.K., Saydy A.A., Orteney Yu.K., Balakhonov S.V. Efficiency of human plague vaccination in Tuvinian natural plague focus. Message 2: Dynamics of immune status indicators after revaccination. Acta biomedica scientifica. 2021; 6(5): 44-56. doi: 10.29413/ABS.2021-6.5.5 
Чума - опасное природно-очаговое заболевание представлявшее в прошлом большую опасность для человечества и унёсшее множество человеческих жизней, которое остаётся серьёзной инфекционной проблемой и для современного мира. Эпидемические проявления чумы в 2010-2019 гг. зарегистрированы на территории 11 государств; общее число случаев заболеваний составило 6367 (3 спорадических случая бубонной чумы произошли в Российской Федерации), из них летальных - 871 [1, 2]. В 2020 г. заболевания человека возбудителем чумы были зарегистрированы в Демократической Республике Конго, Китае, Монголии и Соединённых Штатах Америки.

На территории России выделяют 11 природных очагов чумы. Прогнозируемое в последние годы обострение эпизоотической обстановки в ряде очагов (Прикаспийском песчаном, Горно-Алтайском высокогорном, Тувинском) ставит вопросы адекватной защиты населения, проживающего на территории очагов, в разряд крайне важных [3, 4].

В Республике Тыва к эндемичным по чуме относятся территории Овюрского, Монгун-Тайгинского и ТесХемского районов, где периодически выделяются штаммы возбудителя у длиннохвостых сусликов [5, 6, 7]. Кроме того, для региона особую опасность представляют природные очаги Монголии, в частности Хархира-Тургенский природный очаг, северные окраины которого примыкают к Монгун-Тайгинскому и Овюрскому кожуунам (районам) Республики Тыва. Вспышки чумы среди жителей, проживающих на территории Хархира-Тургенского природного очага, отмечаются с 1946 г. [8]. В настоящее время в очаге наблюдается активная фаза циркуляции возбудителя чумы основного подвида Yersinia pestis ssp. pestis [7], что создаёт угрозу заноса и распространения его в сибирских регионах Российской Федерации.

Вследствие вышеописанного в комплексе мер по обеспечению эпидемиологического надзора и профилактики чумы в природных очагах инфекции важное место отведено специфической профилактике. В Российской Федерации с этой целью применяется живая чумная вакцина (ЖЧВ) отечественного производства (ФКУЗ Ставропольский научно-исследовательский противочумный институт Роспотребнадзора) на основе штамма Y. pestis EV линии НИИЭГ, способствующая развитию иммунитета против чумы длительностью до 1 года $[9,10]$. Формирование иммунологической перестройки после вакцинации людей ЖЧВ протекает с образованием специфичных антител к капсульному антигену F1 чумного микроба [11], однако в формировании противочумного иммунитета ведущая роль принадлежит клеточному звену иммунной защиты $[12,13]$.

Одной из причин низкой эффективности вакцинопрофилактики рассматриваются генетические и фенотипические особенности формирования иммунного ответа в популяции, что определяет актуальность выработки персонифицированного подхода к вакцинации ЖЧВ $[10,14]$. В связи с этим, совершенствование стратегии проведения мероприятий по специфической и неспецифической профилактике и тактике применения ЖЧВ, в том числе, с учётом конкретных условий сложившейся эпидемиологической ситуации, тесно связано с формированием методологии иммуноэпидемиологического наблюдения за населением, проживающим на территории природных очагов чумы.

Учитывая вышеизложенное, а также результаты, полученные нами ранее [15, 16], проведение иммунологического мониторинга среди местного населения, проживающего на энзоотичной по чуме территориях, с целью определения иммунологической эффективности проводимой специфической профилактики, а также поиска информативных показателей и маркеров поствакцинального противочумного иммунитета является актуальным направлением исследования.

\section{ЦЕЛЬ РАБОТЫ}

Оценить показатели клеточного и гуморального иммунитета у ревакцинированных ЖЧВ людей, постоянно проживающих и осуществляющих свою трудовую деятельность на территории Тувинского природного очага чумы.

\section{МАТЕРИАЛЫ И МЕТОДЫ}

В исследовании приняли участие 76 условно здоровых добровольцев, ранее принимавших участие в научном проекте по оценке эффективности вакцинопрофилактики местного населения в природных очагах чумы Российской Федерации в рамках распоряжения Правительства РФ № 1864-р (05.09.2016) и проживающие на энзоотичной по этой инфекции территории, расположенной в непосредственной близости от Боро-Шайского мезоочага Тувинского природного очага (с. Хандагайты, Овюрский кожуун, Республика Тыва) [16]. Критериями исключения волонтёров из исследования были: возраст моложе 18 лет, отсутствие вакцинации против чумы в предшествующем году. При работе с добровольцами соблюдались этические принципы, предъявляемые Хельсинкской декларацией Всемирной медицинской ассоциации. Все участники прошли предварительное анкетирование и дали письменное информированное согласие для участия в исследовании. Представленная работа была одобрена комитетом по биомедицинской этике при ФКУЗ Иркутский противочумный научно-исследовательский институт Роспотребнадзора (Протокол № 4 от 26.05.2021).

Исследуемая группа людей по этническому признаку была представлена тувинцами. При этом 51 \% приходился на женщин, а 49 \% - мужчин. Большая часть добровольцев входила в возрастную группу от 26 до 50 лет (67\% от общего числа).

Волонтёров прививали коммерческой ЖЧВ, которая представляет собой лиофилизированную живую культуру вакцинного штамма чумного микроба Y. pestis EV линии НИИЭГ, в соответствии с Календарём профилактических прививок по эпидемическим показаниям. Вакци- 
нацию проводили однократно накожным способом, ревакцинацию осуществляли спустя 12 месяцев.

В соответствии с планом комплексного исследования забор периферической крови от добровольцев проводили на протяжении 2018-2019 гг. с помощью вакуумных систем для взятия крови (Vacutest Kima, Италия): 1-й этап - перед вакцинацией ЖЧВ (1-й срок) и через 1 (2-й срок), 3 (3-й срок) и 6 (4-й срок) месяцев после неё; 2-й этап - через 1 (5-й срок), 3 (6-й срок) и 6 (7-й срок) месяцев после ревакцинации. Из крови выделяли сыворотку. Для определения уровня продукции цитокинов кровь предварительно смешивали с питательной средой RPMI 1640 (ООО «ПанЭко», Россия), содержащей 100 мкг/мл гентамицина (ООО «ПанЭко», Россия). В опытные пробы вносили по 100 мкл Т-клеточный митоген конканавалин А (ООО «ПанЭко», Россия) в концентрации 15 мкг/мл, а в контрольные - забуференный физиологический раствор (ЗФР), и инкубировали 24 ч при $37^{\circ} \mathrm{C}$.

Исследование полученного клинического материала проводили согласно разработанным в РосНИПчИ «Микроб» методическим рекомендациям «Оценка уровня иммунитета у лиц, вакцинированных (ревакцинированных) против чумы» (Саратов, 2015 г.), которое включало определение спонтанной и митогениндуцированной

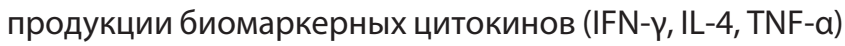
клеток крови, титров специфических антител IgG к капсульному антигену F1 чумного микроба и концентраций основных классов иммуноглобулинов (lgM, $\lg G, \lg A$ и $\lg$ E) в сыворотке крови и иммунофенотипирование лимфоцитов крови (CD3, CD4, CD8, CD16, CD19).

Количественное определение уровня цитокинов в спонтанной/индуцированной лимфоцитарным митогеном конканавалином A (ConA) пробах и основных классов иммуноглобулинов определяли методом твердофазного иммуноферментного анализа (ИФА) с использованием коммерческих тест-систем ЗАО «ВекторБест» (р. п. Кольцово, Новосибирская область) согласно инструкциям производителя. Концентрацию цитокинов выражали в пг/мл, а иммуноглобулинов - в мг/мл (классы M, G и A) и ME/мл (класс Е). Для показателей основных классов иммуноглобулинов использовали референсные значения, приведённые в инструкциях к наборам тестсистем. Для оценки титра специфических антител к капсульному антигену F1 чумного микроба использовали иммуноферментную тест-систему «ИФА-Ат-Ф1 Yersinia pestis» (ФКУЗ РосНИПЧИ «Микроб», г. Саратов). Учёт оптической плотности осуществляли на автоматическом ридере ELx 808 IU (Biotek Instruments Inc, США).

Фенотип лимфоцитов определяли с использованием сертифицированныхмоноклональных антител (МКАТ, производства Becton Dickinson, США) в панели: CD45Alexa 700, CD3-PE-Cy7, CD4-PerCP, CD8-APC-Cy7, CD16-PE, CD19-FITC; для чего готовили «коктейль» моноклональных антител в соответствии с инструкцией производителя. В пробирку для цитофлуориметрического анализа добавляли 50 мкл крови с ЭДТА и 75 мкл коктейля. Лизис эритроцитов проводили с помощью BD FACS ${ }^{\text {TM }}$ Lysing solution (Becton Dickinson, США) согласно инструкции. Анализ окрашенных МКАТ образцов проводили на про- точном цитофлуориметре BD FACSCanto ${ }^{\mathrm{TM}}$ II (Becton Dickinson, США) в программе BD Diva 6.0. В каждой пробе анализировалось не менее 10000 клеток. Для изучения клеточного звена определяли следующие субпопуляции лимфоцитов: Т-лимфоциты $\left(\mathrm{CD}^{+}\right)$, Т-хелперы $\left(\mathrm{CD}^{+}{ }^{+} \mathrm{CD} 4^{+}\right)$, цитотоксические Т-лимфоциты $\left(\mathrm{CD}^{+}{ }^{+} \mathrm{CD} 8^{+}\right)$, NK-клетки (CD3-CD16 ${ }^{+}$и и В-лимфоциты (CD19+). Иммунорегуляторный индекс (ИРИ) рассчитывали по формуле: ИРИ $=\mathrm{CD}^{+}{ }^{+} \mathrm{CD}^{+} / \mathrm{CD}^{+}{ }^{+} \mathrm{CD} 8^{+}$; значения индекса выражали в условных единицах (у. е.).

Статистическую обработку данных проводили с использованием пакета прикладных программ «STATISTICA» версия 6.1. Для проверки нормальности сравниваемых выборок применяли критерии Колмогорова - Смирнова и Шапиро - Уилка, для определения равенства дисперсий - критерий Левена. Так как выборки не соответствовали критериям нормальности, а также отсутствовало равенство дисперсий, то сравнительный анализ проводили с использованием непараметрических критериев Уилкоксона и Фридмана для парных и множественных сравнений соответственно и корреляционного анализа Спирмена $\left(r_{s}\right)$. Полученные данные выражали в виде медианы (Me) и диапазона квартильных отклонений (Q25\%-Q75\%). При этом различия считали статистически значимыми при $p<0,05$.

\section{РЕЗУЛЬТАТЫ И ОБСУЖДЕНИЕ}

Материалы данной работы (2-й этап исследований) базируются на результатах, полученных при оценке эффективности вакцинации местного населения против чумы, проводимых в Республике Тыва в 2018 г. (1-й этап) [16] и являются продолжением комплексной научной темы в рамках распоряжения Правительства РФ № 1864p (05.09.2016) [17].

Ранее нами было показано статистически значимое снижение концентрации IgM спустя 1, 3, 6 месяцев и IgG через 1 месяц после вакцинации ЖЧВ в сыворотке крови добровольцев в сравнении со значениями до её проведения [16]. Во 2-м этапе исследования (после ревакцинации ЖЧВ) концентрация IgG превышала величину показателя до вакцинации в 1,3 раза (табл. 1) на 5-й срок наблюдения $(p=0,01)$ и в 1,5 раза на 6-й срок $(p=0,05)$, a IgM - в 1,7 раза на 6-й срок наблюдения $(p=0,01)$. Примечательно, что после ревакцинации медианные значения концентрации этих иммуноглобулинов несколько превышали значения физиологической нормы, тем не менее, к 7-му сроку они статистически значимо снижались. Согласно результатам, полученным после ревакцинации исследуемой группы добровольцев, регистрировалось повышение концентрации lgM и lgG по сравнению с данными после вакцинации $(p<0,001)$. В ходе статистического анализа взаимосвязей между показателями 2-го срока установлены корреляционные связи концентрации IgG со спонтанной продукцией IL-4, IgM, IgA, CD19+-клетками $\left(r_{s}=0,44\right.$, $0,48,0,34$ и 0,4 соответственно; $p<0,05)$ и с $\mathrm{CD}^{+} \mathrm{CD}^{+}-$ лимфоцитами $\left(r_{s}=-0,37 ; p<0,05\right)$. Обращает на себя вни- 
мание сохранение взаимосвязи $\lg \mathrm{G}$ с $\lg \mathrm{M}$ и $\lg$ А на 3-м $\left(r_{s}=0,51\right.$ и 0,64; $\left.p<0,05\right)$ и 4-м $\left(r_{s}=0,75\right.$ и 0,8; $\left.p<0,05\right)$ сроках соответственно. Выявленные корреляционные взаимосвязи указывают на влияние ЖЧВ на продукцию основных классов иммуноглобулинов (lgG, $\lg M$ и $\lg \mathrm{A})$ B-лимфоцитами при участии IL-4, который модулирует функциональное состояние В- и Т-лимфоцитов крови, в начальные сроки после вакцинации (1-3-й месяц).
ТАБЛИЦА 1

ДИНАМИКА ОСНОВНЫХ КЛАССОВ ИММУНОГЛОБУЛИНОВ ПОСЛЕ РЕВАКЦИНАЦИИ ЖЧВ, Me (Q25\%-Q75\%)
TABLE 1

DYNAMICS OF THE MAJOR IMMUNOGLOBULIN CLASSES AFTER REVACCINATION, Me (Q25\%-Q75\%)

\begin{tabular}{|c|c|c|c|c|c|}
\hline \multirow{2}{*}{ Показатель } & \multirow{2}{*}{$\begin{array}{c}\text { Референсные } \\
\text { значения }\end{array}$} & \multirow{2}{*}{$\begin{array}{c}\text { До вакцинации } \\
\text { (1-й срок) }\end{array}$} & \multicolumn{3}{|c|}{ После ревакцинации, месяц } \\
\hline & & & 1-й (5-й срок) & 3-й (6-й срок) & 6-й (7-й срок) \\
\hline $\operatorname{lgG}$, мг/мл & $7,0-16,0$ & $13,4(9,0-21,2)$ & $17,0(15,2-22,6) * *$ & $19,6(16,0-24,7)$ * & $9,6(8,6-12,0)$ \\
\hline $\operatorname{lgM}$, мг/мл & $0,4-2,3$ & $1,8(1,2-2,6)$ & $2,0(1,4-2,9)$ & $3,0(2,4-3,7) *$ & $1,4(1,2-1,9) *$ \\
\hline $\operatorname{lgA}$, мг/мл & $0,7-4,0$ & $1,3(0,9-2,0)$ & $4,0(3,5-5,2) * * *$ & $3,8(3,5-4,7)^{* * *}$ & $2,3(1,6-2,6) * * *$ \\
\hline IgE общ., ME/мл & $0-100$ & $25,0(10,0-130,0)$ & $15,0(5,0-48,0) * *$ & $20,0(4,1-57,0) * * *$ & $44,0(14,0-131,0)$ \\
\hline
\end{tabular}

Примечание. ${ }^{*}-p<0,05,{ }^{* *}-p<0,01,{ }^{* * *}-p<0,001$ уровни статистической значимости по отношению к значениям показателя до проведения вакцинации.

$\lg \mathrm{E}$

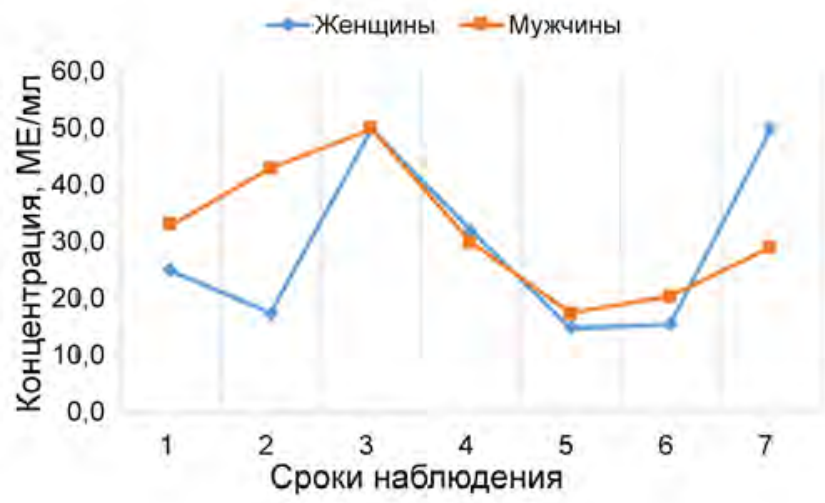

$\lg M$

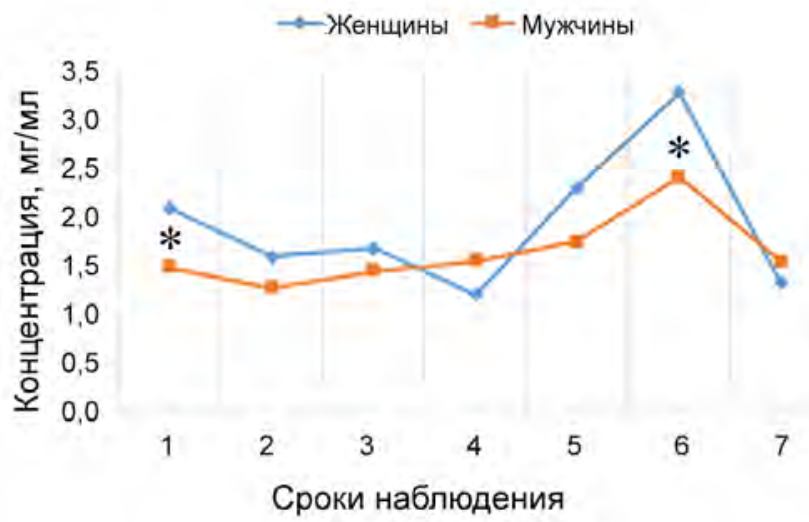

Рис. 1.

Динамика основных классов иммуноглобулинов у вакцинированных/ревакцинированных ЖЧВ мужчин и женщин, Ме: 1 - 1-й срок; 2 - 2-й срок; 3 - 3-й срок; 4 - 4-й срок; 5 - 5-й срок; 6-6-й срок; 7- 7-й срок; ${ }^{*}-p<0,001$, уровень статистической значимости группы мужчин в сравнении с группой женщин
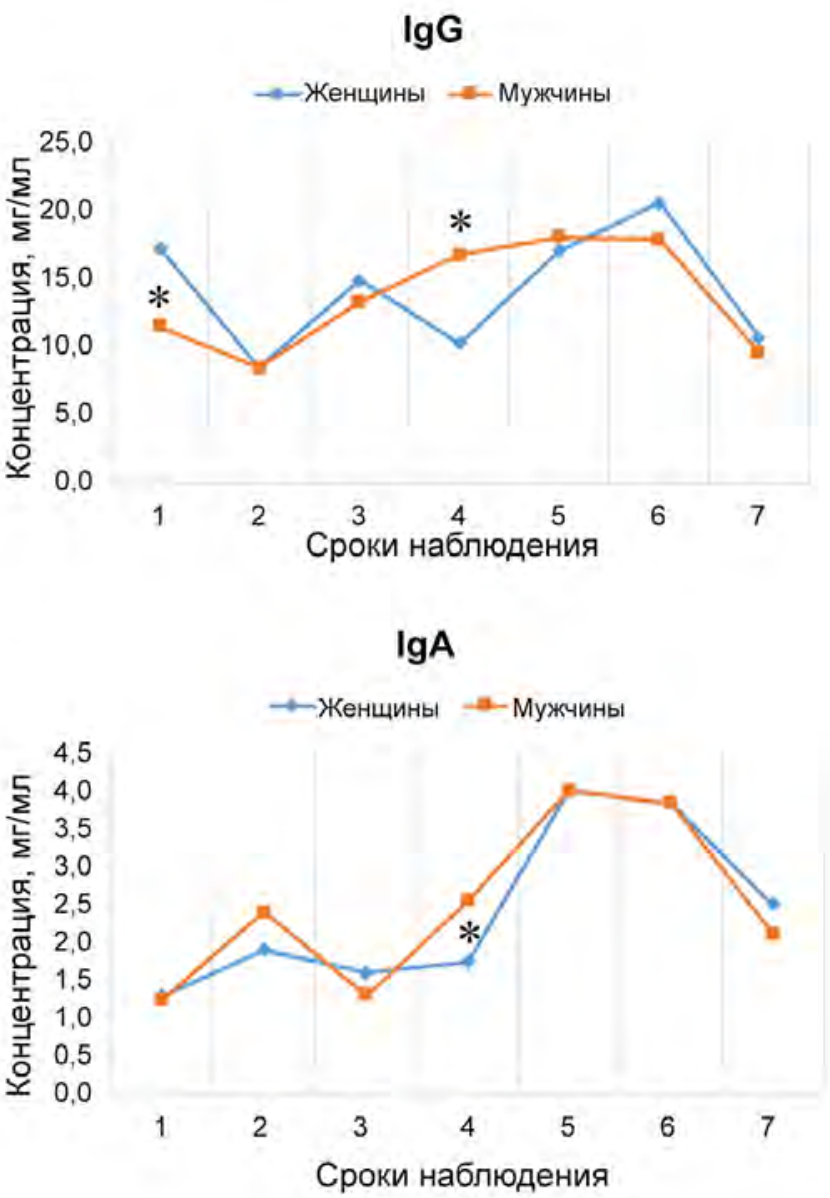

FIG. 1.

Dynamics of the main classes of immunoglobulins in vaccinated/revaccinated men and women, Me: 1 - period 1;2-period 2; 3 - period 3; 4 - period 4; 5 - period 5; 6 - period 6; 7 - period 7 ; ${ }^{*}-p<0.001$, statistical significance level of group of men in comparison with group of women 
На 1-м этапе исследования было отмечено повышение концентрации $\lg$ А через 1 месяц после вакцинации (1,9мг/ мл $(1,4-2,4)$ по сравнению с показателями до вакцинации 1,3 мг/мл (0,9-2,0)), тем не менее в последующие 2 срока статистически значимых отличий не обнаружено. Уровень $\lg$ А в сыворотке крови людей после ревакцинации варьировался аналогично изменениям концентрации lgG - через 1, 3 и 6 месяцев зафиксировано повышение концентрации в $3,1,2,9$ и 1,8 раза соответственно $(p<0,001)$.

Сравнительный анализ уровня IgE показал отсутствие статистически значимых различий после вакцинации. В то же время после ревакцинации, содержание lgE статистически значимо ниже (5-6-е сроки), чем было до вакцинации $(p<0,01)$. Выявленные особенности показателей содержания иммуноглобулинов $\lg \mathrm{A}$ и $\lg$ в в сыворотке варьировали в пределах референсных значений.

На рисунке 1 продемонстрирована динамика основных классов иммуноглобулинов в зависимости от гендерной принадлежности. Показано, что у мужчин уровни lgG и IgМ до вакцинации статистически значимо ниже, чем у женщин. Общее повышение концентрации IgM через 3 месяца после ревакцинации (табл. 1) обусловлено в большей степени увеличением IgM среди женщин. Уровни $\operatorname{lgG}$ и $\lg$ А на 4-й срок (3 месяца после вакцинации) были статистически значимо выше у мужчин.

На 1-м этапе исследования нами было показано [16], что у 86 \% добровольцев положительная сероконверсия наблюдалась через 1 месяц после вакцинации ЖЧВ, средний титр составлял $1: 156,3$.Уровень специфических антител к фракции 1 чумного микроба, превышающий диагно- стический титр, равный $1: 80$, был установлен в $37 \%$ случаев (рис. 2). На 3-м сроке наблюдения средний титр был 1 : 137, и лишь в $6 \%$ случаев уровень антител не превышал значения диагностического титра. Спустя полгода уровень специфических IgG в сыворотке крови сохранялся у 87 \% добровольцев (титр АТ на уровне диагностического).

После ревакцинации уровень специфических антител к F1 чумного микроба значительно повышался на 5-й срок исследования в 91 \% случаев титр превышал диагностический (средний титр составил 1 : 573,3). Схожие результаты были получены спустя 3 месяца после ревакцинации, лишь у 4 \% добровольцев титр IgG к капсульному антигену чумного микроба был равен $1: 80$. Тем не менее, к 7-му сроку специфические антитела были обнаружены лишь у 5 \% добровольцев. В ходе статистического анализа взаимосвязей между показателями установлена положительная корреляция титра IgG к F1 с общим lgG $\left(r_{s}=0,43, p<0,05\right)$, а также спонтанной продукцией IFN- $\gamma$ через $1\left(r_{s}=0,49, p<0,05\right)$ и $3\left(r_{s}=0,30, p<0,05\right)$ месяца после вакцинации, что может свидетельствовать о преобладании Тh1-зависимого клеточного иммунного ответа.

Как нами было показано ранее, на 1-м этапе комплексного исследования статистически значимое снижение концентрации IFN- $\gamma$, IL-4 и TNF-a в спонтанных и индуцированных пробах было выявлено на 2-й срок наблюдения (1 месяц после вакцинации), также выявлено их последующее повышение спустя 3 и 6 месяцев в сравнении с величиной показателей до вакцинации [16]. На 2-м этапе исследования, через 1 месяц после ревакцинации, регистрировалось повышение продук-

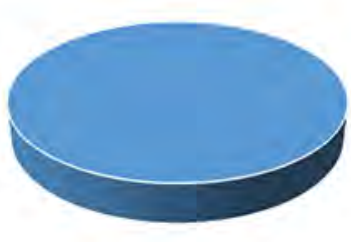

a

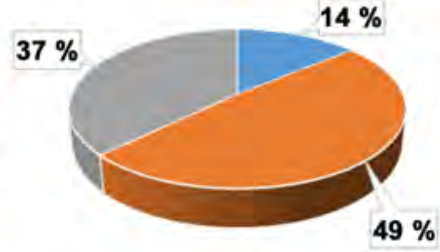

6

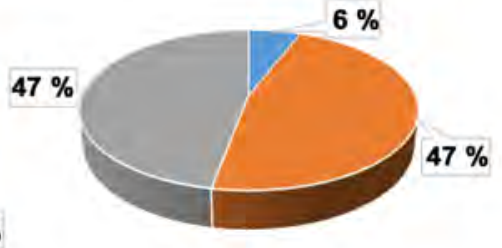

B

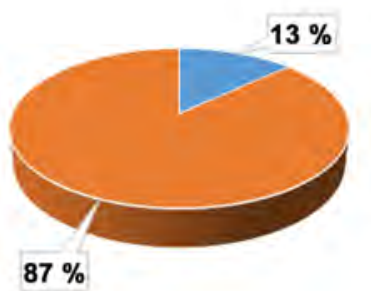

$\mathbf{r}$

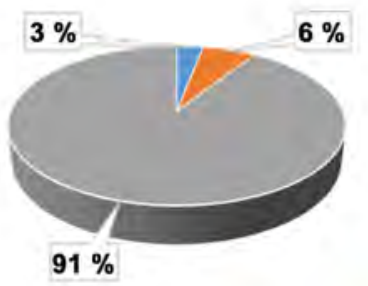

A

1

\section{РИС. 2.}

Прочентное соотношение титров антител к F1 Y. pestis улюдей, вакцинированных/ревакцинированных ЖЧВ;

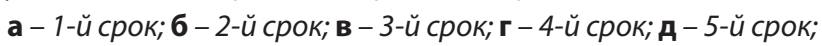
е - 6-й срок; ж - 7-й срок; 1 - титр АТ меньше диагностического; 2 - титр АТ на уровне диагностического; 3 - титр АT выше диагностического (согласно инструкции производителя диагностический титр составляет $1: 80$ )

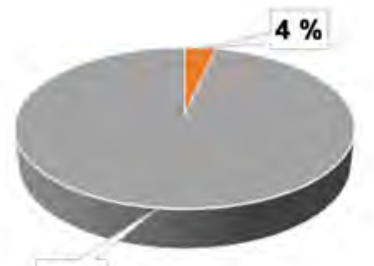

$96 \%$

e

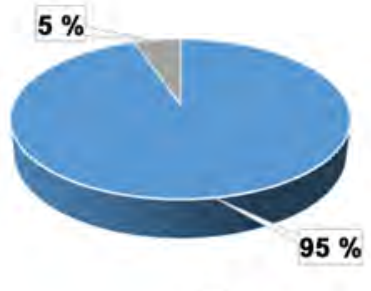

$\mathbf{W}$

\section{FIG. 2.}

Percentage ratio of antibody titre to $F 1 Y$. pestis in humans vaccinated by live plague vaccine: a - period 1; 6 - period 2; B - period 3; $\mathbf{r}$ - period 4; $\mathbf{A}$ - period $5 ; \mathbf{e}$ - period $6 ; \boldsymbol{ж}$ - period $7 ; 1$ - antibody titre is less than diagnostic; 2 - antibody titre at the diagnostic level; 3 - antibody titre higher than diagnostic (diagnostic titre is $1: 80$ according to the manual) 
ции IFN-ү в спонтанных пробах в 3,4 раза в сравнении с исходным уровнем и TNF-a - через 1 и 3 месяца в 2,3 и 7,0 раз соответственно (табл. 2). Величина спонтанной выработки IFN-ү на 5-й срок превышала уровень IFN-үчерез 1 месяц после вакцинации $(p=0,001)$. Также медиана концентрации IFN- $\gamma$ спустя 1 месяц после ревакцинации была в 1,5 раза выше, чем через 6 месяцев после вакцинации ( $p=0,0001)$, в то время как продукция TNF-a находилась на том же уровне. После ревакцинации ЖЧВ в отношении изменения продукции противовоспалительного цитокина IL-4 (табл. 2), так же как и после вакцинации, установлено статистически значимое снижение концентрации через 1 месяц ( $p<0,001)$ и повышение через 3 месяца до исходных значений показателя.

Статистически значимое повышение продукции IL-4 под влиянием митогена установлено на 5-й срок (через

\section{ТАБЛИЦА 2}

\section{СПОНТАННАЯ И ИНДУЦИРОВАННАЯ ПРОДУКЦИЯ ЦИТОКИНОВ (ТNF- $\alpha$, IFN- $\gamma$ И IL-4) У ЛЮДЕЙ, РЕВАКЦИНИРОВАННЫХ ЖЧВ, Ме (Q25\%-Q75\%)}

TABLE 2

SPONTANEOUS AND INDUCED CYTOKINE PRODUCTION
(TNF- $a$, IFN-ץ AND IL-4) IN PEOPLE REVACCINATED
BY LIVE PLAGUE VACCINE, Me (Q25\%-Q75\%)

\begin{tabular}{|c|c|c|c|c|c|c|c|c|}
\hline \multirow{3}{*}{$\begin{array}{c}\text { Показатель, } \\
\text { пг/мл }\end{array}$} & \multirow{3}{*}{$\begin{array}{c}\text { До } \\
\text { ревакцинации } \\
\text { (1-й срок) } \\
\text { СП }\end{array}$} & \multicolumn{7}{|c|}{ После ревакцинации, месяц } \\
\hline & & \multicolumn{2}{|c|}{ 1-й (5-й срок) } & \multicolumn{2}{|c|}{ 3-й (6-й срок) } & \multicolumn{2}{|c|}{ 6-й (7-й срок) } & \multirow[b]{2}{*}{ ип } \\
\hline & & иП & $\mathrm{C} \Pi$ & иП & $\mathrm{C} \Pi$ & иП & $\mathrm{C} \Pi$ & \\
\hline TNF-a & $\begin{array}{c}60 \\
(60-103)\end{array}$ & $\begin{array}{c}99,5 \\
(60-250)\end{array}$ & $\begin{array}{c}140 \\
(100-290) *\end{array}$ & $\begin{array}{c}220 \\
(130-420)\end{array}$ & $\begin{array}{c}420 \\
(330-495) *\end{array}$ & $\begin{array}{c}380 \\
(280-510) *\end{array}$ & $\begin{array}{c}450 \\
(270-690) * * *\end{array}$ & $\begin{array}{c}710 \\
(680-930) * * *\end{array}$ \\
\hline IFN- $\gamma$ & $\begin{array}{c}100 \\
(0-280)\end{array}$ & $\begin{array}{c}240 \\
(6-350)\end{array}$ & $\begin{array}{c}340 \\
(260-380) *\end{array}$ & $\begin{array}{c}400 \\
(300-620) *\end{array}$ & $\begin{array}{c}80 \\
(50-110)\end{array}$ & $\begin{array}{c}145 \\
(110-225)\end{array}$ & $\begin{array}{c}43 \\
(25-100)\end{array}$ & $\begin{array}{c}250 \\
(170-340)\end{array}$ \\
\hline IL-4 & $\begin{array}{c}3,0 \\
(1,0-6,2)\end{array}$ & $\begin{array}{c}5,0 \\
(2,3-6,4)\end{array}$ & $\begin{array}{c}0 \\
(0-0) *\end{array}$ & $\begin{array}{c}0,8 \\
(0-1,0) \text { * }\end{array}$ & $\begin{array}{c}5,0 \\
(3,5-6,5)\end{array}$ & $\begin{array}{c}5,0 \\
(3,5-6,5)\end{array}$ & $\begin{array}{c}1,8 \\
(0,8-1,8) * *\end{array}$ & $\begin{array}{c}2,7 \\
(1,8-3,4) * *\end{array}$ \\
\hline
\end{tabular}

Примечание. СП - спонтанная продукция цитокинов; ИП - индуцированная продукция цитокинов; ${ }^{*}-p<0,05,{ }^{* *}-p<0,01,{ }^{* * *}-p<0,001$, уровни статистической значимости по отношению к значениям показателя до проведения вакцинации.
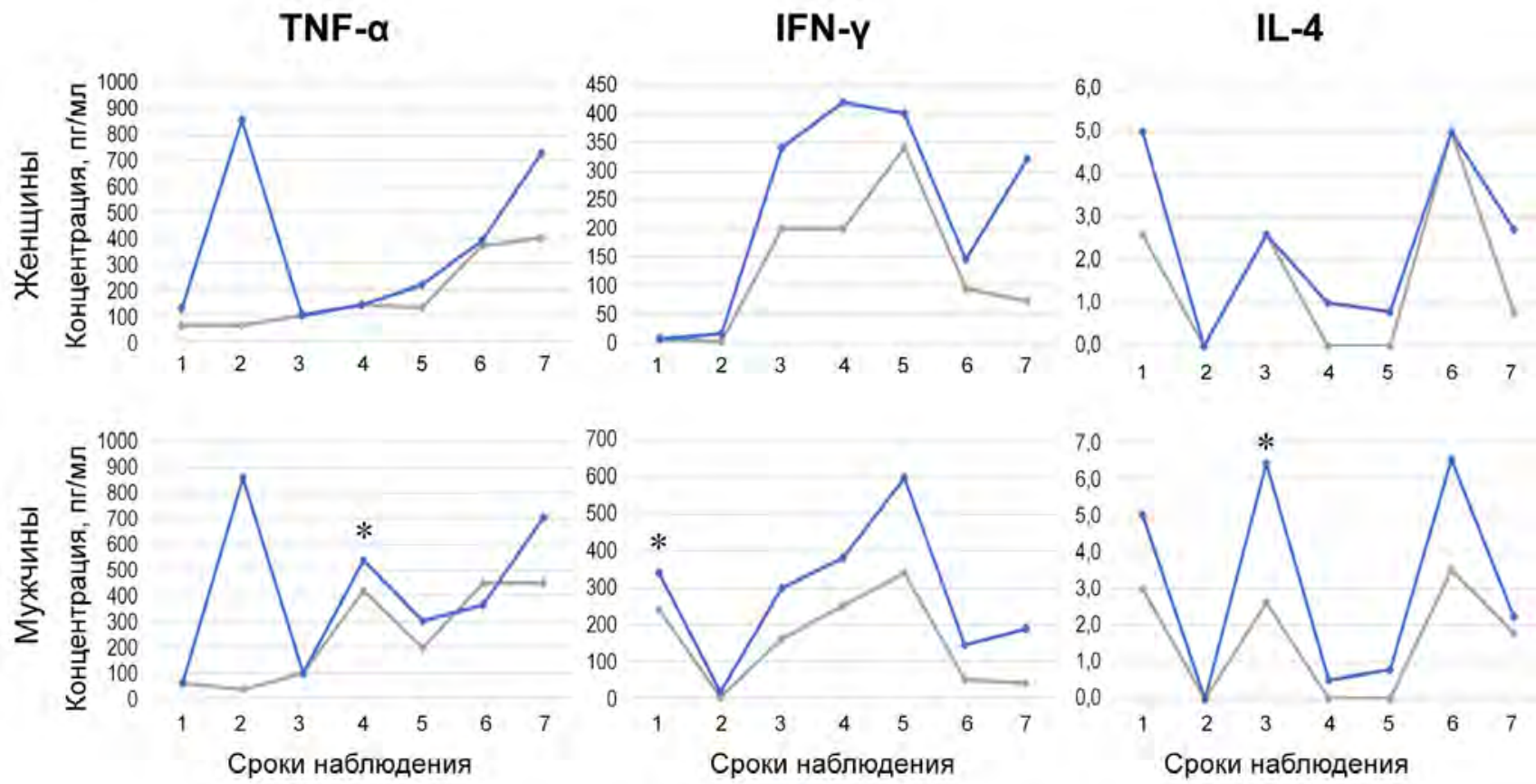

- Спонтанная продукция

\section{РИС. 3.}

Динамика спонтанной/индуцированной продукции цитокинов у вакцинированных/ревакцинированных ЖЧВ мужчин и женщин, Ме: 1 - 1-й срок; 2 - 2-й срок; 3-3-й срок; 4-4-й срок; 5 - 5-й срок; 6 - 6-й срок; 7 - 7-й срок; * - $>$ <0,001, уровень статистической значимости в сравнении с женщинами

\section{- Индуцированная продукция}

FIG. 3.

Dynamics of spontaneous/induced production of cytokines in vaccinated/revaccinated live plague vaccine men and women, Me: 1 - period 1;2-period 2; 3 - period 3;4-period 4; 5 - period 5; 6 -period $6 ; 7$ - period $7 ;{ }^{*}-p<0.001$, statistical significance level in comparison with group of women 
1 месяц после ревакцинации ЖЧВ). Через 3 и 6 месяцев после ревакцинации подобных различий между показателями продукций цитокина отмечено не было. В целом уровень индуцированной продукции IL-4 полностью повторяет характер изменений концентрации этого цитокина в спонтанных пробах.

Способность лимфоцитов крови кповышениюпродукции цитокинов под влиянием ConA сохранялась и после ревакцинации. Стоит отметить, что спонтанная продукция
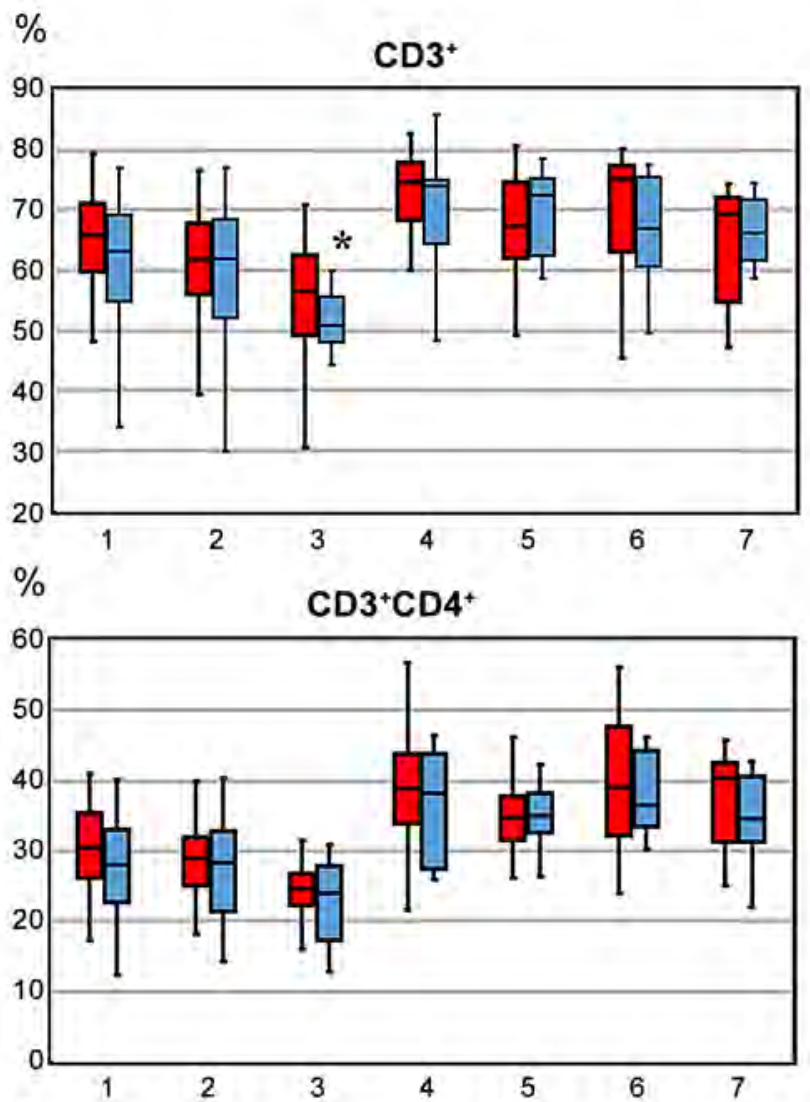

$\%$

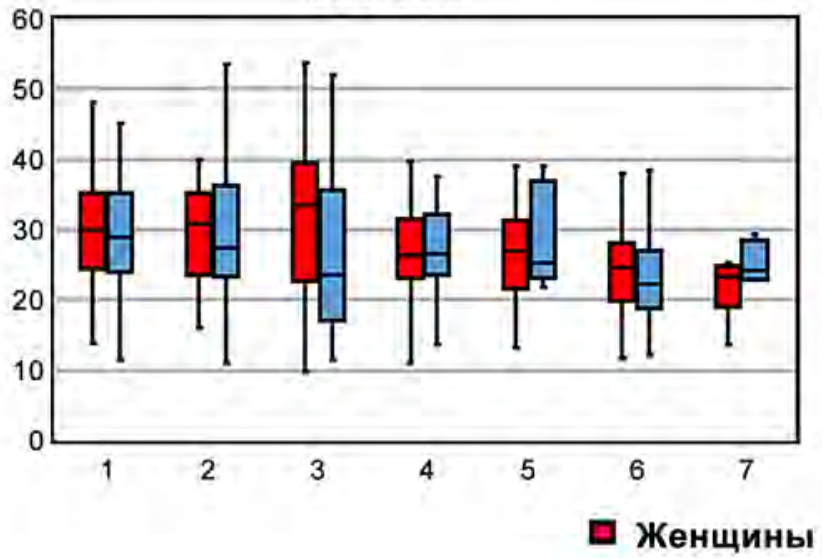

РИС. 4.

Динамика клеток крови увакцинированных/ревакцинированных ЖЧВ мужчин и женщин, Ме (Q25\%-Q75\%): 1 - 1-й срок; 2 - 2-й срок; 3 - 3-й срок; 4 - 4-й срок; 5 - 5-й срок; 6 - 6-й срок; 7 - 7-й срок; * - $p<0,001$, уровень статистической значимости в сравнении с женщинами
TNF-a через 1 месяц после ревакцинации ЖЧВ статистически значимо выше в 3,3 раза $(p<0,001)$, а митогениндуцированная выработка данного цитокина в 3,9 раза ниже аналогичных показателей у вакцинированных (2-й срок). Высокий уровень продукции TNF-а в спонтанных пробах сохранялся также на 6-й и 7-й сроки наблюдения.

Различия продукции цитокинов в зависимости от гендерной принадлежности представлены на рисунке 3. У мужчин зафиксированы более высокие медиан-

y.e.

ИРИ
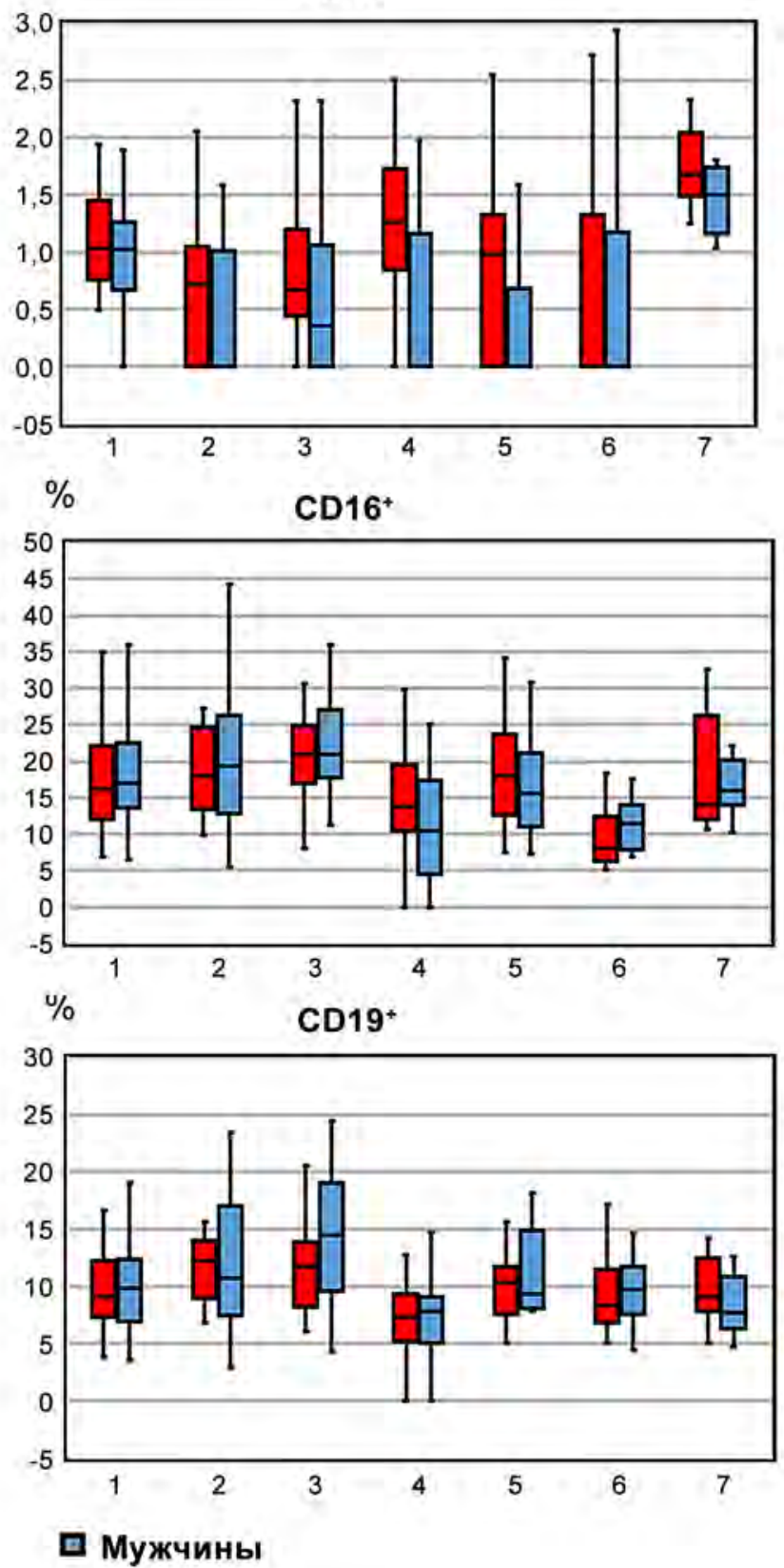

FIG. 4.

Dynamics of blood cells in men and women vaccinated/revaccinated with HPV, Me (Q25\%-Q75\%): 1 - period 1; 2 - period 2; 3 - period 3; 4 - period 4; 5 - period $5 ; 6$ - period $6 ; 7$ - period $7 ;{ }^{*}-p<0.001$, statistical significance level in comparison with women 
ные значения показателя IL-4 в индуцированных пробах через 3 месяца после вакцинации $(p<0,001)$, а также TNF-a как в спонтанных, так и в индуцированных пробах на 4-й срок наблюдения по сравнению с женской группой $(p<0,001)$.

Также стоит отметить, что использованный в исследованиях лимфоцитарный митоген ConA не является антигеном Y. pestis, поэтому позволяет лишь косвенно свидетельствовать об активации и функциональном состоянии иммунокомпетентных клеток организма, вакцинированного против чумы. Применение специфических ассоциированных с чумным микробом антигенов при работе с клиническим материалом вакцинированных/ревакцинированных людей при количественном определении уровня цитокинов и изучении клеточного звена иммунитета должно позволить корректно оценить изменения показателей иммунной системы в ответ на введение ЖЧВ.

Сравнительный анализ популяционного состава клеток крови выявил статистически значимое снижение $\mathrm{CD}^{+}{ }_{-}^{-}$ клетокчерез 1 и 3 месяца после вакцинации ЖЧВ по сравнению с исходным уровнем (1-й этап исследований) [16]. Статистически значимое повышение $\mathrm{CD}^{+}{ }^{-}$-клетокв 1,1 раза отмечено на 4-й срок, величина этого показателя, тем не менее, находилась в диапазоне физиологической нормы. Медиана процентного содержания Т-лимфоцитов в крови женщин на 3-й срок статистически значимо в 1,1 раза выше в сравнении с мужчинами ( $p=0,015 ;$ рис. 4).

Таким образом, изменения в содержании Т-лимфоцитов, выявленные в ходе 1-го этапа исследования, носили характер перераспределения их популяций и выражались в статистически значимом увеличении $\mathrm{CD}^{+} \mathrm{CD}^{+}{ }_{-}^{-}$ лимфоцитов через 1 месяц, снижении уровня $\mathrm{CD}^{+} \mathrm{CD}^{+}{ }_{-}^{-}$

\section{ТАБЛИЦА 3}

ДИНАМИКА СОДЕРЖАНИЯ НАТУРАЛЬНЫХ КИЛЛЕРОВ,
Т- И В-ЛИМФОЦИТОВ В КРОВИ РЕВАКЦИНИРОВАННЫХ
ПРОТИВ ЧУМЫ ЛЮДЕЙ, Ме (Q25\%-Q75\%) клеток спустя 3 месяца и статистически значимом повышении уровня Т-хелперов через 6 месяцев после вакцинации при одновременном снижении процентного содержания цитотоксических Т-лимфоцитов [16]. Важно отметить, что содержание Т-хелперов после ревакцинации также оставалось значительно выше в сравнении с данными перед вакцинацией, а также в 1,2 и 1,6 раза по сравнению со 2-м (28,3 \% (23,8-32,8)) и 3-м $(24,3 \%(20,5-26,7))$ сроками наблюдения соответственно ( $p<0,001$, табл. 3).

После ревакцинации ЖЧВ процентное содержание $\mathrm{CD}^{+}$-клеток оставалось на относительно высоком уровне $(p<0,05)$ по сравнению с величиной показателя до вакцинации (табл. 3).

Динамика содержания В-клеток крови соответствует текущему вакцинальному процессу: повышение их относительного содержания после вакцинации [16] и постепенное снижение в период после ревакцинации (табл. 3). Величина показателя при этом варьирует в пределах нормальных значений. Содержание $\mathrm{CD} 19^{+}$-лимфоцитов через 3 месяца после ревакцинации ЖЧВ коррелировало с повышенным содержанием IgG в сыворотке крови испытуемых $\left(r_{s}=0,43 ; p<0,05\right)$, что свидетельствует об активации функционального состоянии В-клеток в реализации поствакцинального иммунного ответа.

В случае $\mathrm{CD}^{+} \mathrm{CD}^{+}$-лимфоцитов отмечалась тенденция к снижению величины показателя после ревакцинации ЖЧВ при сравнении с данными от 1-го срока наблюдения (табл. 4). Статистически значимых различий в динамике процентного содержания Т-хелперов и CD3+CD8+-клеток между мужчинами и женщинами не выявлено (рис. 4).

При анализе иммунорегуляторного индекса (ИРИ) установлено, что происходит изменение данного пока-

TABLE 3

DYNAMICS OF CONTENT OF NATURAL KILLER CELLS, T- AND B-LYMPHOCYTES IN BLOOD OF PEOPLE REVACCINATED AGAINST PLAGUE, Me (Q25\%-Q75\%)

\begin{tabular}{lcccc}
\hline \multicolumn{1}{c}{ Показатель, \% } & $\begin{array}{c}\text { До вакцинации } \\
(1-\text { ср срок) }\end{array}$ & 1-й (5-й срок) & 3-й (6-й срок) & П-й (7-й срок) \\
\hline $\mathrm{CD}^{+}$ & $64,9(58,1-70,1)$ & $70,1(62,8-74,4) * *$ & $71,0(62,9-77,0) * *$ & $67,7(60,2-71,8) *$ \\
$\mathrm{CD}^{+}{ }^{+} \mathrm{CD} 4^{+}$ & $29,6(24,5-33,5)$ & $34,7(32,6-37,7) * *$ & $38,2(33,9-44,4)^{* *}$ & $38,4(31,8-42,3) * *$ \\
$\mathrm{CD}^{*}{ }^{*} \mathrm{CD} 8^{+}$ & $29,4(24,1-35,1)$ & $26,9(21,9-31,2) * *$ & $23,3(19,6-28,0)^{* *}$ & $23,5(22,8-25,3) * *$ \\
$\mathrm{CD}^{*} 6^{+}$ & $16,7(12,9-21,9)$ & $17,4(12,5-22,8)$ & $8,6(7,1-12,8)^{* *}$ & $15,3(13,1-22,1)$ \\
$\mathrm{CD} 19^{+}$ & $9,5(7,2-12,3)$ & $9,8(8,1-11,7)$ & $9,0(7,1-11,5)^{*}$ & $9,1(6,7-11,9)^{* *}$ \\
\hline
\end{tabular}

Примечание. ${ }^{*}-p<0,05,{ }^{* *}-p<0,01$, уровни статистической значимости по отношению к значениям показателя до проведения вакцинации.

ТАБЛИЦА 4

ДИНАМИКА ИММУНОРЕГУЛЯТОРНОГО ИНДЕКСА У РЕВАКЦИНИРОВАННЫХ ЖЧВ, Ме (Q25\%-Q75\%)
TABLE 4

DYNAMICS OF IMMUNOREGULATORY INDEX IN PEOPLE REVACCINATED AGAINST PLAGUE, Me (Q25\%-Q75\%)

\begin{tabular}{|lcccc}
\hline \multicolumn{1}{r}{ Показатель } & До вакцинации & \multicolumn{3}{c}{ После ревакцинации, месяц } \\
& $(1-$ й срок) & 1 -й (5-й срок) & 3-й (6-й срок) & 6-й (7-й срок) \\
\hline ИРИ, у. е. & $1,0(0,8-1,3)$ & $1,3(1,1-1,6) * *$ & $1,7(1,3-2,2)^{* *}$ & $1,7(1,3-1,8)^{* *}$ \\
\hline
\end{tabular}

Примечание. ${ }^{*}-p<0,01,{ }^{* *}-p<0,001$, уровни статистической значимости по отношению к значениям показателя до проведения вакцинации. 
зателя на 3-й срок наблюдения за счёт сниженного уровня Т-хелперов. Для первых трёх сроков наблюдения характерны низкие значения ИРИ, что связано со снижением содержания $\mathrm{CD}^{+} \mathrm{CD}^{+}{ }^{+}$-лимфоцитов (ниже референсных значений) [16].

На 1-м этапе исследований нами показано, что повышение ИРИ через 6 месяцев после вакцинации связано сувеличениемдоли Т-хелперов [16]. Отмеченоувеличение ИРИ на фоне повышения содержания Т-хелперов в крови через 1, 3 и 6 месяцев после ревакцинации ЖЧВ $\left(r_{s}=0,65\right.$ и $r_{s}=0,7$ соответственно, $p<0,05 ;$ табл. 4). Статистически значимых различий в динамике медианных значений ИРИ между мужчинами и женщинами не обнаружено (рис. 4).

Сравнительный анализ содержания NK-клеток на 1-м и 2-м этапах исследования показал, что после вакцинации их содержание увеличивается в 1,1-1,2 раза и снижается в 1,2 раза спустя полгода $(p<0,001)$, а после ревакцинации снижается в 1,9 раза по сравнению с показателями до вакцинации. К 7-му сроку наблюдения значение показателя NK-клеток повышается до исходного уровня, что связано с участием этих клеточных факторов в механизмах неспецифической резистентности.

\section{ЗАКЛЮЧЕНИЕ}

В ходе комплексного иммунологического исследования иммунизированного ЖЧВ населения, проживающего на территории Тувинского природного очага чумы, были получены результаты, которые позволили установить ряд важнейших показателей. Было показано, что изменения концентраций иммуноглобулинов основных классов имеет фазный характер - снижение ( $\operatorname{lgG}$ и $\lg M)$ или повышение (lgA) после вакцинации ЖЧВ и повышение (lgG, $\lg$ М и $\lg A)$ после ревакцинации. Повторная вакцинация ЖЧВ приводит к увеличению числа вакцинированного контингента людей с более высокими титрами специфических IgG к капсульному антигенy F1 Y. pestis в сыворотке крови, которые коррелируют с повышением общих lgG. Также корреляционные взаимосвязи были обнаружены между иммуноглобулинами, В-лимфоцитами и IL-4.

Об активации звеньев гуморального иммунитета организма людей, вакцинированных/ревакцинированных против чумы, также свидетельствует динамика изменения субпопуляционного состава (увеличение Т-хелперов и В-лимфоцитов), а клеточного иммунитета - существенное повышение спонтанной и индуцированной продукции про- и противовоспалительных цитокинов, а также статистически значимые изменения в отношении показателей субпопуляционного состава крови вакцинированных/ревакцинированных: возрастание процентного содержания натуральных киллеров, незначительное снижение Т-хелперов в крови, сопровождающееся понижением ИРИ.

В ходе исследования установлены статистически значимые различия показателей иммуноглобулинового и цитокинового статуса у мужчин и женщин. Так, уровни $\operatorname{lgG}$ и IgM до вакцинации были ниже у мужчин, чем ужен- щин. Общее повышение концентрации IgM через 3 месяца после ревакцинации обусловлено в большей степени увеличением IgM среди женщин. Кроме того, у мужчин зафиксированы более высокие медианные значения IFN-ү (до вакцинации), TNF-a (4-й срок) и IL-4 (3-й срок) как в спонтанных, так и в индуцированных пробах в сравнении с женской частью группы. Тем не менее, отмеченные различия показателей между женщинами и мужчинами не воспроизводятся в другие сроки наблюдения, что свидетельствует о частном характере и может быть связано с иного рода факторами сравниваемых групп, поэтому данные отличия не должны расцениваться как систематическое явление и требуют дополнительного уточнения.

Таким образом, результаты иммунологического наблюдения за вакцинированными против чумы лицами в Тувинском природном очаге чумы свидетельствуют об активации у обследованных людей звеньев гуморального и клеточного иммунитета и отсутствии повреждающего действия вакцины на клетки иммунной системы. Показатели иммунного статуса вакцинированных/ревакцинированных людей варьируют в пределах референсных значений, что свидетельствует о безопасности этой вакцины. Однако часть отмеченных колебаний иммунных реакций нивелируются по прошествии 6 месяцев после ревакцинации, возвращаясь к исходному уровню. Поэтому для полного понимания развития и сохранения адекватного противочумного иммунитета необходимо продолжить проведение ежегодного иммунологического мониторинга за населением, проживающим на территории Тувинского природного очага чумы и вакцинирующимся живой чумной вакциной, с привлечением дополнительных современных методик исследования и иммунодиагностических препаратов.

\section{Конфликт интересов}

Авторы данной статьи сообщают об отсутствии конфликта интересов.

\section{ЛИТЕРАТУРА}

1. Попов Н.В., Ерошенко Г.А., Карнаухов И.Г., Кузнецов А.А., Матросов А.Н., Иванова А.В. и др. Эпидемиологическая и эпизоотическая обстановка по чуме в Российской Федерации и прогноз ее развития на 2020-2025 гг. Проблемы особо опасных инфекций. 2020; (1): 43-50. doi: 10.21055/0370-10692020-1-43-50

2. Bertherat E. Plague around the world in 2019. Wkly Epidemiol Rec. 2019; 94(25): 289-292

3. Кутырев В.В., Попова А.Ю., Ежлова Е.Б., Демина Ю.В., Пакскина Н.Д., Безсмертный В.Е. и др. Обеспечение эпидемиологического благополучия по чуме в условиях обострения эпизоотической обстановки в Прикаспийском песчаном природном очаге в 2014 г. Проблемы особо опасных инфекций. 2015; (4): 22-29.

4. Попов Н.В., Безсмертный В.Е., Матросов А.Н., Князева Т.В., Кузнецов А.А., Федоров Ю.М. и др. Эпизоотическая активность природных очагов чумы Российской Федерации 
в 2015 г. и прогноз на 2016 г. Проблемы особо опасных инфекций. 2016; (1): 13-19. doi: 10.21055/0370-1069-2016-1-13-19

5. Попов Н.В., Кузнецов А.А., Матросов А.Н., Корзун В.М., Вержуцкий Д.Б., Вершинин С.А. и др. Эпизоотическая активность природных очагов чумы Российской Федерации в 2008-2017 гг. и прогноз на 2018 г. Проблемы особо опасных инфекций. 2018; (1): 50-55. doi: 10.21055/0370-1069-2018-150-55

6. Балахонов С.В., Вержуцкий Д.Б., Иннокентьева Т.И. Эпидемиологическая оценка современного состояния природных очагов чумы в Сибири. Эпидемиология и вакцинопрофилактика. 2010; 2(51): 34-37.

7. Холин А.В., Шаракшанов М.Б., Вержуцкий Д.Б., Корзун В.М., Оргилбаяр Л., Ганхуяг Ц. и др. Результаты эпизоотологического обследования приграничной с Россией части Хархира-Тургенского природного очага чумы Монголии в 2019 г. Проблемы особо опасных инфекций. 2020; (2): 129-134. doi: 10.21055/0370-1069-2020-2-129-134

8. Летов Г.С., Абрамова Г.С. Бухмуринская вспышка легочной чумы. Известия Иркутского противочумного института. 1959; (20): 107-110.

9. Feodorova VA, Sayapina LV, Corbel MJ, Motin VL. Russian vaccines against especially dangerous bacterial pathogens. Emerg Microb Infect. 2014; 3(12): e86. doi: 10.1038/emi.2014.82

10. Зверев В.В., Семенов Б.Ф., Хаитов Р.М. Вакцины и вакцинация: национальное руководство. М.: ГЭОТАР-Медиа; 2011.

11. Rajerison M, DartevelleS, Ralafiarisoa LA, Bitam I,Tuyet Dinh Thi Ngoc, Andrianaivoarimanana V, et al. Development and evaluation of two simple, rapid immunochromatographic tests for the detection of Yersinia pestis antibodies in humans and reservoirs. PLOS Neg/ Trop Dis. 2009; 3(4): e421. doi: 10.1371/journal.pntd.0000421

12. Levy $Y$, Flashner $Y$, Tidhar A, Zauberman A, Aftalion $M$, Lazar $\mathrm{S}$, et al. $\mathrm{T}$ cells play an essential role in anti-F1 mediated rapid protection against bubonic plague. Vaccine. 2011; 29(40): 6866-6873. doi: 10.1016/j.vaccine.2011.07.059

13. Philipovskiy AV, Smiley ST. Vaccination with live Yersinia pestis primes CD4 and CD8 T cells that synergistically protect against lethal pulmonary $Y$. pestis infection. Infect Immun. 2007; 75(2): 878-885. doi: 10.1128/IAI.01529-06

14. Брико Н.И. Оценка качества и эффективности иммунопрофилактики. Лечащий врач. 2012; (10): 57-64.

15. Корытов К.М., Войткова В.В., Дубровина В.И., Носков А.К., Мищенко А.И., Михайлов Е.П. и др. Оценка иммунологической эффективности вакцинации населения против чумы в Горно-Алтайском высокогорном природном очаге. Эпидемиология и вакцинопрофилактика. 2018; 17(6): 87-97. doi: 10.31631/2073-3046-2018-17-87-97

16. Корытов К.М., Войткова В.В., Дубровина В.И., Пятидесятникова А.Б., Носков А.К., Глушков Э.А. и др. Оценка эффективности вакцинации населения против чумы в Тувинском природном очаге. Acta biomedica scientifica. 2019; 4(5): 31-37. doi: 10.29413/ABS.2019-4.5.5

17. Бугоркова С.А., Щуковская Т.Н., Микшис Н.И., Клюева С.Н., Кудрявцева О.М., Кравцов А.Л. и др. Комплексное иммунологическое исследование вакцинированных живой чумной вакциной лиц, проживающих на территории Прикаспийского песчаного очага чумы в Республике Калмыкия. Эпидемиология ивакцинопрофилактика. 2018;3(100): 38-49. doi: 10.31631/20733046-2018-17-3-38-50

\section{REFERENCES}

1. Popov NV, Eroshenko GA, Karnaukhov IG, Kuznetsov AA, Matrosov AN, Ivanova AV, et al. Epidemiological and epizootic situation on plague in the Russian Federation and forecast for its development for 2020-2025. Problems of Particularly Dangerous Infections. 2020; (1): 43-50. (In Russ.). doi: 10.21055/0370-10692020-1-43-50

2. Bertherat E. Plague around the world in 2019. Wkly Epidemiol Rec. 2019; 94(25): 289-292.

3. Kutyrev VV, Popova AYu, Ezhlova EB, Demina YuV, Pakskina ND, Bezsmertny VE, et al. Provision of epidemiological welfare on plague under aggravation of epizootic situation in the PreCaspian sandy natural plague focus in 2014. Problems of Particularly Dangerous Infections. 2015; (4): 22-29. (In Russ.).

4. Popov NV, Bezsmertny VE, Matrosov AN, Knyazeva TV, Kuznetsov AA, Fedorov YuM, et al. Epizootic activity of natural plague foci of the Russian Federation in 2015, and prognosis for 2016. Problems of Particularly Dangerous Infections. 2016; (1): 13-19. (In Russ.). doi: 10.21055/0370-1069-2016-1-13-19

5. Popov NV, Kuznetsov AA, Matrosov AN, Korzun VM, Verzhutsky DB, Vershinin SA, et al. Epizootic activity of natural plague foci of the Russian Federation in 2008-2017 and forecast for 2018. Problems of Particularly Dangerous Infections. 2018; (1): 50-55. (In Russ.). doi: 10.21055/0370-1069-2018-1-50-55

6. Balakhonov SV, Verzhutski DB, InnokentjevaTI. Epidemiological evaluation of the current state of natural focus plague in Siberia. Epidemiology and Vaccinal Prevention. 2010; 2(51): 34-37. (In Russ.).

7. Kholin AV, Sharakshanov MB, Verzhutsky DV, Korzun VM, Orgilbayar L, Gankhuyag T, et al. Results of epizootiological survey along the border areas of Kharkhira-Turgensky natural plague focus between Russia and Mongolia in 2019. Problems of Particularly Dangerous Infections. 2020; (2): 129-134. (In Russ.). doi: 10.21055/03701069-2020-2-129-134

8. Letov GS, Abramova GS. Bukhmurinsk outbreak of pneumonic plague. Izvestiya Irkutskogo Protivochumnogo Instituta. 1959; 20: 107-110. (In Russ.).

9. Feodorova VA, Sayapina LV, Corbel MJ, Motin VL. Russian vaccines against especially dangerous bacterial pathogens. Emerg Microb Infect. 2014; 3(12): e86. doi: 10.1038/emi.2014.82

10. Zverev VV, Semenov BF, Khaitov RM. Vaccines and vaccinations: National guidelines. Moscow: GEOTAR-Media; 2011. (In Russ.).

11. Rajerison M, DartevelleS, Ralafiarisoa LA, Bitam I, Tuyet Dinh Thi Ngoc, Andrianaivoarimanana V, et al. Development and evaluation of two simple, rapid immunochromatographic tests for the detection of Yersinia pestis antibodies in humans and reservoirs. PLOS Neg/ Trop Dis. 2009; 3(4): e421. doi: 10.1371/journal.pntd.0000421

12. Levy $Y$, Flashner $Y$, Tidhar A, Zauberman A, Aftalion M, Lazar $S$, et al. T cells play an essential role in anti-F1 mediated rapid protection against bubonic plague. Vaccine. 2011; 29(40): 6866-6873. doi: 10.1016/j.vaccine.2011.07.059

13. Philipovskiy AV, Smiley ST. Vaccination with live Yersinia pestis primes $\mathrm{CD} 4$ and $\mathrm{CD} 8 \mathrm{~T}$ cells that synergistically protect against lethal pulmonary $Y$. pestis infection. Infect Immun. 2007; 75(2): 878-885. doi: 10.1128/IAI.01529-06

14. Briko NI. Assessment of the quality and effectiveness of immunization. Lechashchiy vrach. 2012; (10): 57-64. (In Russ.).

15. Korytov KM, Voitkova VV, Dubrovina VI, Noskov AK, Mishchenko Al, Mikhailov EP, et al. Immunological efficiency of human 
plague vaccination in the Gorno-Altai high-mountain natural plague focus. Epidemiology and Vaccinal Prevention. 2018; 17(6): 87-97. (In Russ.). doi: 10.31631/2073-3046-2018-17-87-97

16. Korytov KM, Voitkova VV, Dubrovina VI, Pyatidesyatnikova $A B$, Noskov AK, Glushkov EA, et al. Efficiency of human plague vaccination in Tuvinian natural plague focus. Acta biomedica scientifica. 2019; 4(5): 31-37. (In Russ.). doi: 10.29413/ABS.2019-4.5.5
17. Bugorkova SA, Shchukovskaya TN, Mikishis NI, Klyueva SN, Kudryavtseva OM, Kravtsov AL, et al. Comprehensive immunological study of persons vaccinated with live plague vaccine living on the territory of the Pre-Caspian sand foci of the plague in the Republic of Kalmykia. Epidemiology and Vaccinal Prevention. 2018; 17(3): 38-50. (In Russ.). doi: 10.31631/2073-30462018-17-3-38-50

\section{Сведения $0 б$ авторах}

Корытов Константин Михайлович - научный сотрудник лаборатории патофизиологии, ФКУз Иркутский научно-исследовательский противочумный институт Сибири и Дальнего Востока Федеральной службы по надзору в сфере защиты прав потребителей и благополучия человека, e-mail: konstmikhkor@yandex.ru, https://orcid.org/0000-0003-1137-6049 Дубровина Валентина Ивановна - доктор биологических наук, заведующая лабораторией патофизиологии, ФКУз Иркутский научно-исследовательский противочумный институт Сибири и Дальнего Востока Федеральной службы по надзору в сфере защиты прав потребителей и благополучия человека, e-mail: dubrovina-valya@mail.ru, https://orcid.org/0000-0001-8561-6207 Войткова Валентина Владимировна - кандидат биологических наук, старший научный сотрудник лаборатории патофизиологии, ФКуз Иркутский научно-исследовательский противочумный институт Сибири и Дальнего Востока Федеральной службы по надзору в сфере защиты прав потребителей и благополучия человека, е-таil: vvoitkova@mail.ru, https://orcid.org/0000-0002-0685-7625

Пятидесятникова Анна Борисовна - младший научный сотрудник лаборатории патофизиологии, ФКУз Иркутский научно-исследовательский противочумный институт Сибири и Дальнего Востока Федеральной службы по надзору в сфере защиты прав потребителей и благополучия человека, e-mail:smy_irkutsk@mail.ru, https://orcid.org/0000-0002-6381-4517 Глушков эдуард Анатольевич - директор, ФКУЗ «Тувинская противочумная станция» Федеральной службы по надзору в сфере защиты прав потребителей и благополучия человека Акимова Ирина Сергеевна - заместитель директора, ФКУЗ «Тувинскаяпротивочумная станция» Федеральной службыпо надзору в сферезащиты прав потребителей и благополучия человека Ондар Ненила Валерьевна - заведующая эпидемиологическим отделом, ФКУЗ «Тувинская противочумная станция» Федеральной службы по надзору в сфере защиты прав потребителей и благополучия человека

Салчак Людмила Кимовна - руководитель Управления Федеральной службы по надзору в сфере защиты прав потребителей и благополучия человека по Республике Тыва Сайды Алимаа Алексеевна - руководитель Территориального отдела Управления Федеральной службы по надзору в сфере защиты прав потребителей и благополучия человека по Республике Тыва в Овюрском районе

Ортеней Юрий Кан-оолович - и. о. главного врача, ГБУЗ РТ «Овюрская центральная кожуунная больница»

Балахонов Сергей Владимирович - доктор медицинских наук, профессор, директор, ФКУз Иркутский научно-исследовательский противочумный институт Сибири и Дальнего Востока Федеральной службы по надзору в сфере защиты прав потребителей и благополучия человека, e-mail: balakhonov.irk@mail.ru, https://orcid.org/0000-0003-4201-5828

\section{Information about the authors}

Konstantin M. Korytov - Research Officer, Pathophysiological Laboratory, Irkutsk Antiplague Research Institute of Siberia and Far East of Rospotrebnadzor, e-mail: konstmikhkor@yandex.ru, https://orcid.org/0000-0003-1137-6049

Valentina I. Dubrovina - Dr. Sc. (Biol.), Head of the Pathophysiological Laboratory, Irkutsk Antiplague Research Institute of Siberia and Far East of Rospotrebnadzor, e-mail: dubrovinavalya@mail.ru, https://orcid.org/0000-0001-8561-6207

Valentina V. Voytkova - Cand. Sc. (Biol.), Senior Research Officer at the Pathophysiological Laboratory, Irkutsk Antiplague Research Institute of Siberia and Far East of Rospotrebnadzor, e-mail: vvoitkova@mail.ru, https://orcid.org/0000-0002-0685-7625

Anna B. Pyatidesyatnikova - Junior Research Officer at the Pathophysiological Laboratory, Irkutsk Antiplague Research Institute of Siberia and Far East of Rospotrebnadzor, e-mail: smy_irkutsk@mail.ru, https://orcid.org/0000-0002-6381-4517

Eduard A. Glushkov - Director, Tuvinian Antiplague Station of Rospotrebnadzor

Irina S. Akimova - Deputy Director, Tuvinian Antiplague Station of Rospotrebnadzor

Nenila V. Ondar - Head of Epidemiology Department, Tuvinian Antiplague Station of Rospotrebnadzor

Lyudmila K. Salchak - Head, Regional Office of Rospotrebnadzor in Republic of Tuva

Alimaa A. Saydy - Head, Territorial Office of Rospotrebnadzor in Ovyur District

Yuri K. Orteney - Acting Chief Physician, Ovyur Central Kozhuun Hospital

Sergey V. Balakhonov-Dr. Sc. (Med.), Professor, Director, Irkutsk Antiplague Research Institute of Siberia and Far East of Rospotrebnadzor, e-mail: adm@ @chumin.irkutsk.ru, https://orcid.org/00000003-4201-5828

\section{Вклад авторов}

Корытов К.М. - планирование эксперимента, оперативные командировки, постановка реакций, учёт и анализ результатов, написание статьи.

Дубровина В.И. - планирование эксперимента, анализ результатов, написание статьи.

Войткова В.В. - планирование эксперимента, оперативные командировки, анализ результатов, оформление статьи.

Пятидесятникова А.Б. - оперативные командировки, постановка реакций, учёт результатов.

Глушков Э.А. - работа с населением по подбору добровольцев, подготовка забора материала для исследования.

Акимова И.С. - работа с населением по подбору добровольцев, подготовка забора материала для исследования.

Ондар Н.В. - обеспечение забора материала для исследований.

Салчак Л.К. - планирование научной темы, работа с населением по подбору добровольцев.

Сайды А.А. - работа с населением по подбору добровольцев, обеспечение забора материала для исследования.

Ортеней Ю.К. - обеспечение вакцинации добровольцев и забора материала для исследований.

Балахонов С.В. - планирование научной темы, оформление статьи. 